Original research article

\title{
Evaluation of anti-methicillin-resistant Staphylococcus aureus property of zerumbone
}

\author{
Shaymaa Fadhel Abbas Albaayit ${ }^{1 *}$, Rukesh Maharjan ${ }^{2}$, Rasedee Abdullah ${ }^{3}$, \\ Mohd Hezmee Mohd Noor ${ }^{4}$ \\ ${ }^{1}$ University of Baghdad, College of Science, Department of Biology, Baghdad, Iraq \\ ${ }^{2}$ University of Karachi, International Center for Chemical and Biological Sciences, H.E.J. Research Institute of Chemistry, Karachi, Pakistan \\ ${ }^{3}$ Universiti Putra Malaysia, Faculty of Veterinary Medicine, Department of Veterinary Laboratory Diagnosis, Serdang, Selangor, Malaysia \\ ${ }^{4}$ Universiti Putra Malaysia, Faculty of Veterinary Medicine, Department of Veterinary Preclinical Sciences, Serdang, Selangor, Malaysia
}

\begin{abstract}
Context and objective: Zerumbone has been reported to exert anti-microbial effects, but the mechanism by which the compound exerts its action is not known. Thus, this study aimed to investigate the mechanism of action of zerumbone against methicillin-resistance Staphylococcus aureus (MRSA), using the atomic force microscopy (AFM), scanning electron microscopy (SEM), and flow cytometry techniques.

Methods: MRSA (NCTC 13277) cell viability was determined using the microplate AlamarBlue assay. AFM and SEM were used to determine the morphology of zerumbone-treated MRSA cells. Flow cytometric analysis was used to determine the effect of zerumbone on bacterial membrane permeability and membrane potential, using the propidium iodide (PI) staining method, membrane potential-sensitive fluorescence probe, and $\mathrm{DiBAC}_{4}(3)$ dye. DCFDA dye was used to determine the generation of reactive oxygen species (ROS) by MRSA. Results: Zerumbone significantly inhibited MRSA growth with a minimum inhibitory concentration (MIC) of $125 \mu \mathrm{g} / \mathrm{ml}$. The AFM analysis showed that zerumbone caused leakage of cytoplasmic content from the bacterial cells. Ultrastructure analysis showed small colonies of the bacteria with pores on the membrane surface. There were increases in zerumbone-treated MRSA PI and DiBAC $(3)$ fluorescence, indicating an increase in cell membrane permeability and a decrease in membrane potential that culminated in the loss of membrane structural integrity and bacterial death. Based on DCFDA dye analysis, zerumbone also reduced ROS production by MRSA.

Conclusions: Zerumbone exerts anti-MRSA effects by causing membrane depolarization, increasing membrane permeability, and finally disrupting cell membrane and bacterial killing.
\end{abstract}

Keywords: Atomic force microscopy; $\mathrm{DiBAC}_{4}(3)$; Flow cytometry; Propidium iodide; Zerumbone

\section{Highlights:}

- Our study evaluated the mechanism of action of zerumbone against Staphylococcus aureus (MRSA).

- Zerumbone inhibited MRSA by membrane disrupting mechanism.

- This work showed the potential of zerumbone for the topical treatment of topical bacterial infections.

\section{Introduction}

The emergence of antibiotic-resistant bacteria has been one of the causes of the increase in the rate of mortality of patients under intensive care (Ibraheem and Al-Mathkhury, 2018). One of the main factors contributing to the increase in antibiotic-resistant bacteria is the rampant use of antibiotics as growth enhancers in livestock feed (Mudzengi et al., 2017). Consequently, much research is being conducted to discover new and more efficacious antibacterial therapeutics that would not develop-resistant strains. Researchers are targeting natural products of plant, animals, and marine sources, for the discovery of compounds with anti-microbial property with minimal adverse effects (Albaayit, 2020; Albaayit et al., 2020a; Dhama et al., 2014). It has been suggested that the antibacterial activities of natural compounds are associated with several mechanisms, including damaging cell membrane, altering the membrane depolarization potential, and increasing membrane permeability (Wu et al., 2016).

Zerumbone, a natural sesquiterpene from edible ginger Zingiber zerumbet Smith, has antimicrobial, anti-inflammatory, immunomodulatory, anticancer, antinociceptive, and antioxidant activities (Albaayit et al., 2021a; Zhang et al., 2012). However, the mechanism of the antibacterial effect of zerumbone is still not clear. In this study, we determined the effect of zerumbone on the methicillin-resistant Staphylococcus aureus (MRSA).

\footnotetext{
* Corresponding author: Shaymaa Fadhel Abbas Albaayit, University of Baghdad, College of Science, Department of Biology, Al Jadriya, Baghdad 10070, Iraq; e-mail: shaymaa_albaayit@yahoo.com http://doi.org/10.32725/jab.2022.002

Submitted: 2020-03-13 • Accepted: 2021-12-09 • Prepublished online: 2022-02-14

J Appl Biomed 20/1: 15-21 • EISSN 1214-0287 • ISSN 1214-021X

(c) 2022 The Authors. Published by University of South Bohemia in České Budějovice, Faculty of Health and Social Sciences.

This is an open access article under the CC BY-NC-ND license.
} 


\section{Materials and methods}

\section{Material}

The zerumbone crystals were prepared, purified, and characterized according to a previous method (Albaayit et al., 2020a). Slices of $Z$. zerumbet were subjected to steam distillation and volatile oil was extracted. The volatile oil was treated with pure hexane with gradual evaporation of solvent in a fuming hood to facilitate crystallization of zerumbone. The process was repeated three times to obtain pure zerumbone crystals, which were stored at $2-8{ }^{\circ} \mathrm{C}$ before use. For each experiment, the zerumbone crystals were diluted with dimethyl sulfoxide (DMSO) to obtain a stock solution of $20 \mathrm{mg} / \mathrm{ml}$ zerumbone. This study was conducted at the Dr. Panjwani Center for Molecular Medicine and Drug Research, International Center for Chemical and Biological Sciences, University of Karachi, Pakistan (June to August, 2018).

\section{Assessment of zerumbone against MRSA}

A broth dilution method for zerumbone as described in the CLSI guidelines (Albaayit, 2021a) was used to determine the antibacterial effect of zerumbone. The stock zerumbone solution was diluted in Mueller Hinton Broth (MHB) medium to obtain concentrations of $15,31.25,62.5,125,250,500$, and $1000 \mu \mathrm{g} / \mathrm{ml}$ zerumbone. Full-grown $S$. aureus cultures (NCTC 13277, MRSA 252) (MRSA) were diluted 1000x in MHB medium and $100 \mu$ l of the bacterial suspension was dispensed to each well containing $100 \mu \mathrm{l}$ diluted zerumbone solution to a final concentration of $0.5 \times 10^{6} \mathrm{CFU} / \mathrm{ml} \mathrm{MRSA}$. The negative control wells contained untreated MRSA. The experiments were conducted in triplicates. The plate was sealed and incubated at $37^{\circ} \mathrm{C}$ for 18 to $20 \mathrm{~h}$. The next day, all wells were visually checked for turbidity, $20 \mu \mathrm{l}$ of AlamarBlue dye was added, and the plate was incubated with shaking for $2 \mathrm{~h}$ at $37^{\circ} \mathrm{C}$ in an incubator. The absorbance was recorded at 570 and $600 \mathrm{~nm}$ in a spectrophotometer (ThermoScientific) and the \% inhibition of bacteria by zerumbone was calculated using the formula described in Lancaster and Fields (1996).

\section{Surface morphology by the atomic force microscopy (AFM)}

The effect of zerumbone on the MRSA was determined using AFM. Bacterial inoculum of $2.5 \times 10^{7} \mathrm{CFU} / \mathrm{ml}$ in Eppendorf tubes was treated with $200 \mu \mathrm{g} / \mathrm{ml}$ zerumbone. The negative (nontreated) control tubes contained medium and bacteria only. After incubation for $2 \mathrm{~h}$, the tubes were centrifuged at $5000 \mathrm{rpm}$ for $5 \mathrm{~min}$, washed twice with double-distilled water, and the supernatant discarded. Pellets formed were dispersed in a small quantity of remaining water in the tube and $10 \mu \mathrm{l}$ of suspension were placed on the poly-L-lysine $(0.01 \%)$ pre-coated silicon wafer slides and allowed to dry (Albaayit, 2021a). The samples were subjected to scanning using AFM (Agilent Technologies-5500, AZ, USA) in the tapping mode. All the topographical images were analyzed using PicoView 1.2 imaging analysis software to get 2D and 3D images of bacteria.

\section{Surface morphology by the scanning electron microscopy (SEM)}

The protocol described by Fischer et al. (2012) was adopted for the study. Mid-exponential grown MRSA at a density of $2.5 \times 10^{7} \mathrm{CFU} / \mathrm{ml}$ in sterile Eppendorf tube were treated with $200 \mu \mathrm{g} / \mathrm{ml}$ zerumbone for $2 \mathrm{~h}$ at $37^{\circ} \mathrm{C}$. This tube was centrifuged at $5000 \mathrm{rpm}$ for $3 \mathrm{~min}$ and the pellet washed with PBS.
The pellet was fixed with $2 \%$ glutaraldehyde for $1 \mathrm{~h}$. The glutaraldehyde was discarded and the pellet again washed with PBS, followed by $50,70,80,90$, and $100 \%$ ethanol. The ethanol was allowed to evaporate at room temperature. The pellet was coated with gold in an ion sputtering device (Jeol JFC-1500, Japan) up to 280-300 A. Scanning electron microscopy was performed with Jeol (JSM 6380A, Japan) to obtain images at $8000 \times$ and $12000 \times$ magnifications.

\section{Determination of cells viability using propidium iodide (PI) dye}

The viability of MRSA treated with $200 \mu \mathrm{g} / \mathrm{ml}$ zerumbone was determined using the PI dye uptake and the BD FACSCELESTA $^{\mathrm{TM}}$ flow cytometer (Becton, Dickinson and Company) and the protocol described by Clementi et al., (2014) with minor modification. $1 \times 10^{7} \mathrm{CFU} / \mathrm{ml}$ of bacterial suspension in PBS was treated with zerumbone for $2 \mathrm{~h}$ before incubating at $37{ }^{\circ} \mathrm{C}$. The negative (nontreated) control MRSA received PBS only. Cells treated with $20 \mu \mathrm{g} / \mathrm{ml}$ Gramicidin were the positive control. The sample in $1 \mathrm{ml}$ phosphate buffer saline (PBS) was then centrifuged twice at $5000 \mathrm{rpm}$ for $5 \mathrm{~min}$. $5 \mu \mathrm{l}$ of PI dye (Sigma Aldrich) from $1 \mathrm{mg} / \mathrm{ml}$ stock solution was added and the cells were incubated at $37^{\circ} \mathrm{C}$ in darkness for $30 \mathrm{~min}$ to allow for dye uptake. The samples were analyzed immediately after incubation, using PI-A filter (EX-535 nm, EM-617 nm) at X-axis, and side-scattered count at Y-axis. Border P3 and P4 represent live and dead cells, respectively. Dead cells with compromised cell membrane showed PI dye staining and fluorescence shifting to the right that is presented by border P4. 10,000 cells in each sample were counted in triplicates.

\section{Membrane potential by the bis-(1,3-dibutylbarbituric acid) trimethine oxonol $\mathrm{DiBAC}_{4}(3)$ dye}

$\mathrm{DiBAC}_{4}(3)$ dye was used to determine changes in bacterial cell membrane potential (Farooq et al., 2014). Briefly, active bacterial MRSA cells at $1 \times 10^{7} \mathrm{CFU} / \mathrm{ml}$ suspended in $1 \mathrm{ml} \mathrm{PBS}$, were treated with $200 \mu \mathrm{g} / \mathrm{ml}$ zerumbone and incubated for $2 \mathrm{~h}$. Cells treated with $20 \mu \mathrm{g} / \mathrm{ml}$ Gramicidin were the positive control. The negative (nontreated) control received PBS only. Then, $5 \mu \mathrm{l}$ of $1.0 \mathrm{mM} \mathrm{DiBAC}_{4}(3)$ was added and the cells were incubated for $20 \mathrm{~min}$ at room temperature. The fluorescence was recorded at the excitation and emission wavelengths of 490 and $516 \mathrm{~nm}$, respectively, using the BD FACSCELESTA ${ }^{\mathrm{TM}}$ flow cytometer. Data were analyzed using BD CellQuestpro software. Border P1 and P2 represent intact and decreased membrane potential cells, respectively. Border P2 showed high fluorescence, indicating the membrane potential of the cells had decreased as the result of zerumbone treatment.

\section{Reactive oxygen species (ROS)}

2', 7'-dichlorofluorescein diacetate (DCFDA) dye was used to determine reactive oxygen species (ROS) generated by zerumbone-treated MRSA (Fang et al., 2019). $1 \times 10^{7}$ CFU/ml MRSA in PBS were incubated with $10 \mu \mathrm{M}$ DCFDA dye for $30 \mathrm{~min}$ before treatment with 300, 200 or $100 \mu \mathrm{g} / \mathrm{ml}$ of zerumbone for $2 \mathrm{~h}$. Then, $200 \mu \mathrm{l}$ of the MRSA suspension were transferred in triplicates to a 96-well white plate for the determination of fluorescence by fluorometry (Tecan, Austria) at excitation/ emission of $485 / 520 \mathrm{~nm}$.

\section{Statistical analysis}

One-way analysis of variance (ANOVA) was used to determine the significance differences between means of treated and nontreated groups at $p<0.05$ (GraphPad Prism software). 


\section{Results}

\section{Anti-MRSA activity of zerumbone}

Change in color of AlamarBlue dye of the bacterial suspension from blue to pink indicated reduction of dye. Blue colored bacterial suspension indicates a reduction in the number of live bacteria. The study showed that zerumbone inhibited MRSA growth $(65.0 \pm 5.8 \%)$ with MIC values of $125 \mu \mathrm{g} / \mathrm{ml}$. Full bacterial growth was observed after treatment with zerumbone at concentrations $<110 \mu \mathrm{g} / \mathrm{ml}$. At $200 \mu \mathrm{g} / \mathrm{ml}$, there was $(80 \pm 5 \%)$ bacterial inhibition. In mechanistic studies, the bacterial count increased, thus, the dose of zerumbone was increased to $200 \mu \mathrm{g} / \mathrm{ml}$ to ensure production of the antibacterial effect.

\section{Effect of zerumbone on the surface morphology of MRSA}

The morphology of MRSA after treatment with zerumbone was visualized using the AFM (Fig. 1) and SEM (Fig. 2) techniques. The AFM (Figs 1A, B) and SEM (Figs 2A, B) images of the nontreated MRSA cells showed clusters of compact cocci with mean diameter of $1 \mu \mathrm{m}$ and typical round shape and intact cell surfaces. However, distinct morphological changes

A

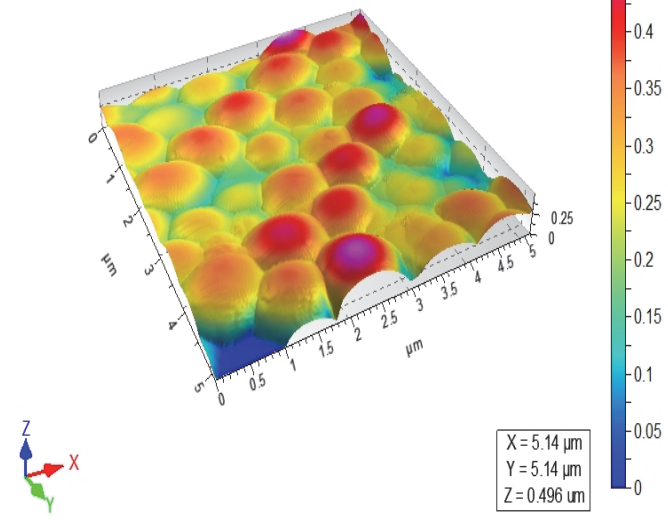

c

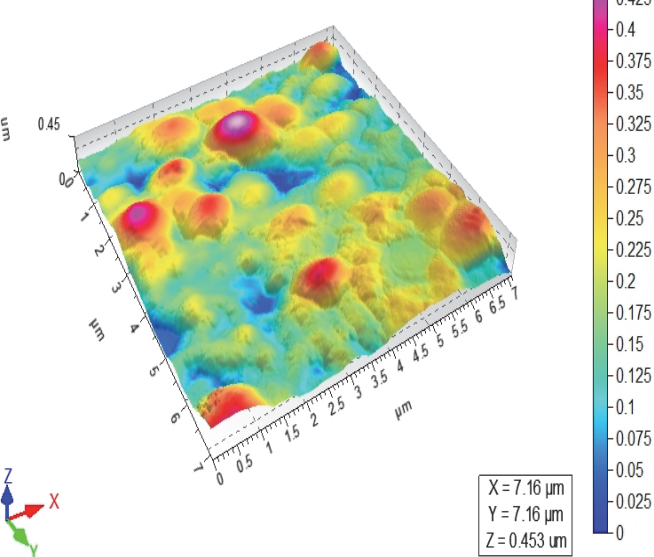

were observed in the bacterial cells treated with zerumbone (Figs 1C, D and Figs 2C, D). The zerumbone-treated bacteria were irregular in shape, with rough surfaces. The cells tended toward loss cluster formation. The cell surface roughness of the bacteria was due to membrane rupture and loss of structural integrity. Fragments of treated cells were observed scattered, the result of spillage of cytoplasmic content.

\section{Membrane potential and membrane permeability of MRSA}

$\operatorname{DiBAC}_{4}(3)$ and propidium iodide dye were used to determine the effects of zerumbone on MRSA cell membrane potential and membrane permeability, respectively. Borders P1 and P2 represent fluorescent data for $\operatorname{DiBAC}_{4}(3)$ dye and border P3 and P4 for PI dye. P2 and P4 showed higher fluorescence, indicating an increase in the number of cells with decreased membrane potential and increased membrane permeability, respectively. The $\mathrm{DiBAC}_{4}(3)$ dye analysis showed that nontreated MRSA (Fig. 3A) had higher P1 (96.2\%) and lower P2 (3.80\%) values, representing a high number of viable cells and stability of cell membrane potential. Upon treatment with gramicidin, a membrane disrupting peptide, the P1 (30.2\%) and P2 (69.7\%) (Fig. 3C) were significantly higher $(p<0.001)$ than that for the nontreated control. The increase in P2 showed that

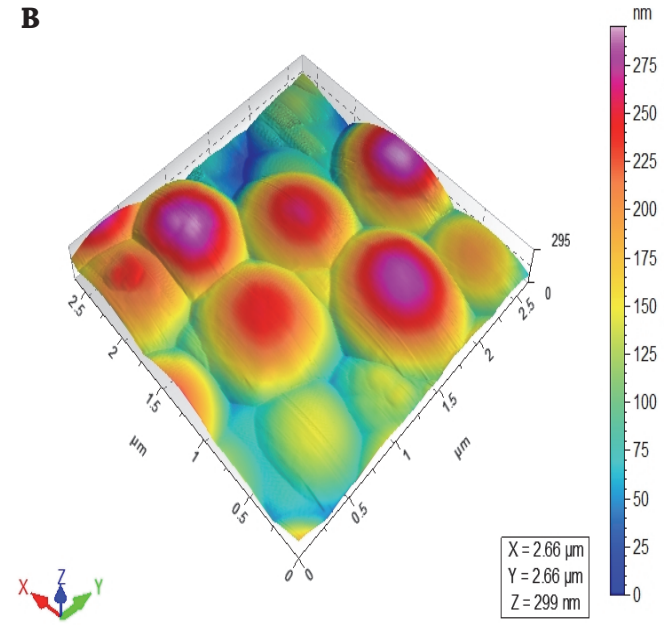

D

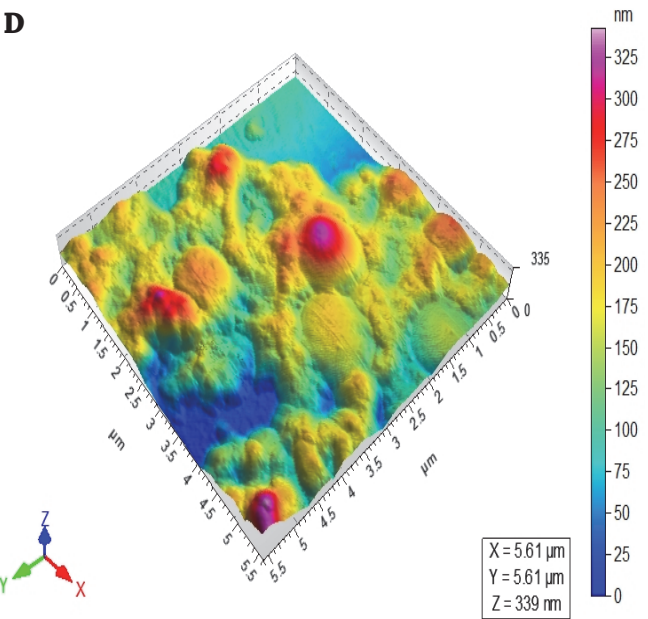

Fig. 1. Atomic force microscopy image of Staphylococcus aureus (NCTC 13277) morphology. (A, B) untreated control, (C, D) treatment with $200 \mu \mathrm{g} / \mathrm{ml}$ zerumbone. 

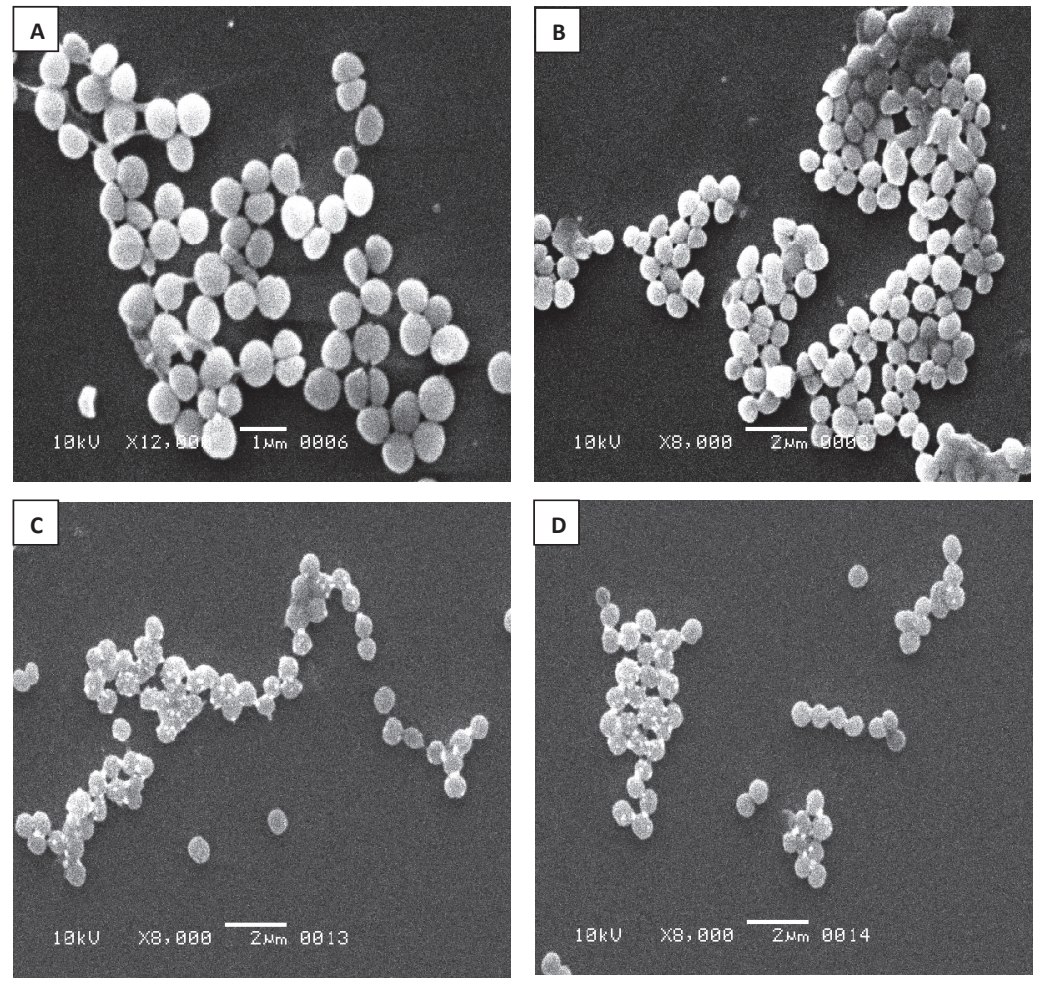

Fig. 2. Scanning electron microscopy (SEM) image of Staphylococcus aureus (NCTC 13277) morphology. (A, B) nontreated control, (C, D) treatment with $200 \mu \mathrm{g} / \mathrm{ml}$ zerumbone.
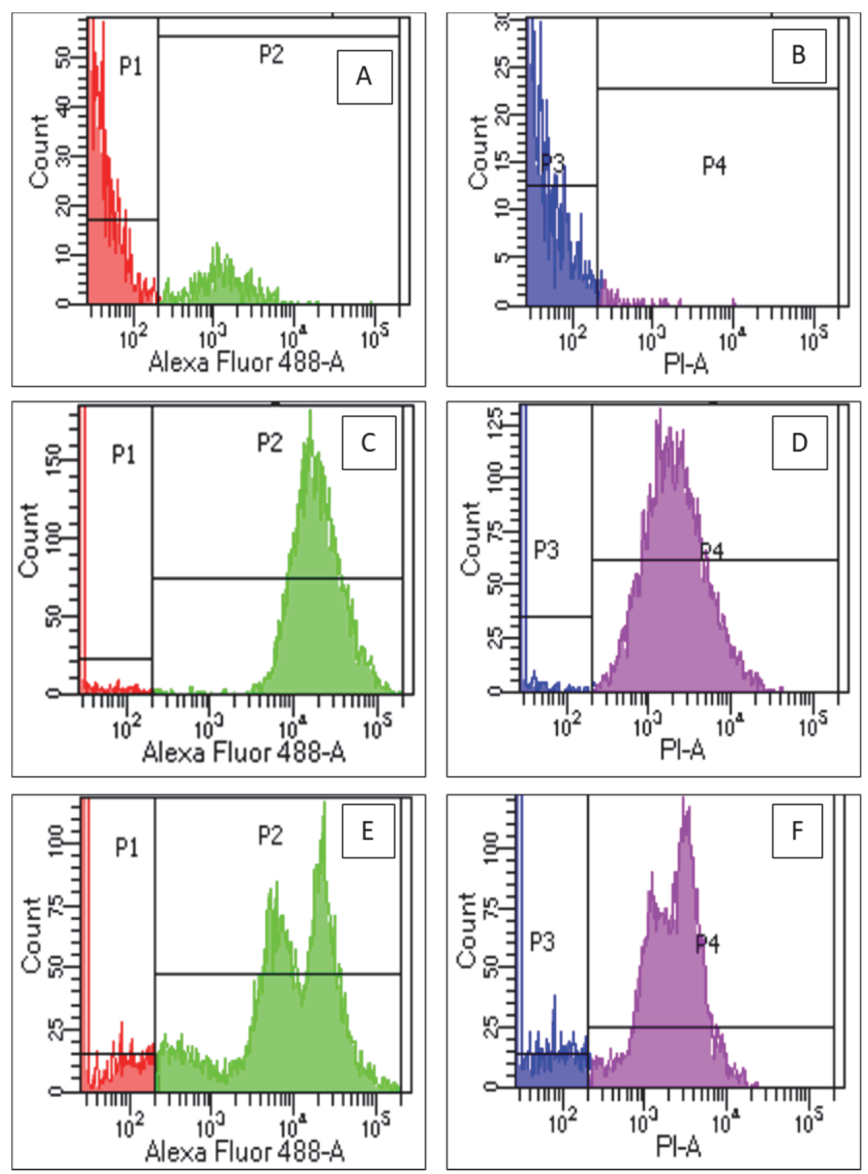

Fig. 3. Alexa Fluor 488-A and PI-A filters representing $\operatorname{DiBAC}_{4}(3)$ and propidium iodide (PI) dye flow cytometry data of MRSA, respectively. $\mathrm{P} 1$ and P2 gating represent the $\mathrm{DiBAC}_{4}(3)$ and P3 and P4 gating represent the PI dye. (A, B) nontreated control, treatment with $(\mathbf{C}, \mathbf{D}) 20 \mu \mathrm{g} / \mathrm{ml}$ Gramicidin and (E, F) $200 \mu \mathrm{g} / \mathrm{ml}$ zerumbone. 
$\mathrm{DiBAC}_{4}(3)$ was absorbed by the cells after treatment due to the rapid decrease in membrane potential leading to higher fluorescence. Most zerumbone-treated cells showed fluorescence of >10,000 RFU and Y-axis count reaching 150, showing that the compound had membrane-disrupting property. With zerumbone treatment, there were similar increases in $\operatorname{DiBAC}_{4}(3)$ P1 (41.2\%) and P2 (58.6\%) fluorescence (Fig. 3E), with two distinct peaks, one below 10,000 RFU and another above 10,000 RFU fluorescence values. The Y-axis count reached 100, which is significantly higher $(p<0.001)$ than that of the nontreated cells. This result showed zerumbone caused a rapid decline in membrane potential and integrity of MRSA cells.

PI uptake assay was also employed to determine membrane integrity of zerumbone-treated MRSA cells. Nontreated control cells showed P3 of $99.7 \%$ and P4 of $0.4 \%$ (Fig. 3B), demonstrating that all cells were viable with intact cell membrane. Upon treatment with gramicidin, the cells showed P3 of $31.6 \%$ and P4 of $68.4 \%$ (Fig. 3D), suggesting significant $(p<0.001)$ increase in PI dye fluorescence of the cells. Gramicidin had disrupted the cell membranes and allowed for increased PI dye penetration, which upon binding with DNA gave high fluorescence. Zerumbone (Fig. 3F) caused an increase in PI fluorescence in the treated cells, which was similar to that shown by the gramicidin treatment. The P3 value of $47.4 \%$ and P4 of $52.6 \%$ showed there was a significant $(p<0.001)$ increase in the zerumbone-treated cells membrane permeability producing two distinct peaks. Thus, the study showed that zerumbone-treatment caused the MRSA to lose cell membrane integrity, confirming the findings from the $\mathrm{DiBAC}_{4}(3)$ uptake assay.

\section{Reactive oxygen species (ROS) generation by MRSA}

DCFDA dye was used to determine the effect of zerumbone on ROS production by MRSA in culture. MRSA was incubated with DCFDA dye before treatment with various concentrations of zerumbone. The ROS production by the cells was determined after $2 \mathrm{~h}$ of incubation. As shown in Table 1, hydrogen peroxide treatment significantly increased MRSA ROS production. Zerumbone treatment dose-dependently reduced ROS production by the bacteria.

Table 1. DCFDA dye fluorescence of MRSA treated with zerumbone

\begin{tabular}{lc}
\hline Treatment & $\begin{array}{c}\text { MRSA relative } \\
\text { fluorescence unit }\end{array}$ \\
\hline Negative (nontreated) & $66.39 \pm 1.46$ \\
Hydrogen peroxide $(50 \mu \mathrm{M})$ & $82.37^{*} \pm 0.99$ \\
Zerumbone $(\mu \mathrm{g} / \mathrm{ml})$ & \\
100 & $47.08^{*} \pm 0.23$ \\
200 & $36.70^{*} \pm 0.25$ \\
300 & $34.85^{*} \pm 0.25$ \\
\hline
\end{tabular}

Values are mean \pm Std. Dev. ${ }^{*}$ Means are significantly different from nontreated control mean at $p<0.001$.

\section{Discussion}

Multidrug resistant bacteria are now widespread, posing great danger to public health. Natural sources are being intensively studied to search for novel compounds that could serve as new and alternative agents in the treatment of microbial infections (Al-Ani et al., 2018; Albaayit and Ozaslar, 2019; Albaayit et al., 2020b, 2021b; Al-Bahrani et al., 2020; Al-Naddawi et al., 2019; Benbelaïd et al., 2014). Among these compounds is zerumbone, known for its many pharmacological activities (Albaayit and Maharjan, 2018; Zhang et al., 2012).

Previous studies have shown that zerumbone inhibits growth of various bacteria, including Helicobacter pylori, Salmonella typhimurium, Bacillus cereus, Escherichia coli, Yersinia enterocolitica, Bacteroides fragilis, Streptococcus mutans (da Silva et al., 2018; Hwang et al., 2019; Kalantari et al., 2017; Santosh Kumar et al., 2013), Staphylococcus epidermidis, Aspergillus niger, Salmonella choleraesuis (Abdul et al., 2008, Vishwanatha et al., 2012), Enterococcus faecalis, Stapylococcus aureus, Pseudomonas aeruginosa, Proteus vulgaris, and Candida albicans (Tian et al., 2020).

Previous studies showed that zerumbone (Abdul et al., 2008) or its open ring derivative 2 (Kitayama et al., 2007) did not inhibit MRSA growth while another study showed zerumbone had anti-MRSA activity (Siddique et al., 2019). It appears that the zerumbone analogues, namely azazerumbone 1 , azazerumbone 2, and zerumbol, also have potent antibacterial activities (Santosh Kumar et al., 2013). Although the anti-bacterial effect of zerumbone remains contentious, our study showed that the compound at $125 \mu \mathrm{g} / \mathrm{ml}$ inhibited the growth of MRSA.

Zerumbone was also reported for its anticancer activities against several cancer cell lines. The mechanism of action of anticancer activities reported includes the molecular modification of different pathways, such as JAK2/STAT3, Akt, and NF- $\kappa B$ (Girisa et al., 2019). In HeLa cancer cell line, zerumbone inhibits the cell proliferation by disrupting the microtubule assembly during the cell division process and shows synergistic effect with paclitaxel (Ashraf et al., 2019). Zerumbone induces apoptosis process in human lymphoma cancer cell line by dysregulating the $\mathrm{Bax} / \mathrm{Bcl}-2$ protein system (Albaayit et al., 2021c). In the colorectal cancer cells, zerumbone exerted its antiproliferative effects by decreasing the mitochondrial membrane potential and activating the intrinsic pathway of apoptosis with the release of activated caspase 3 (Sithara et al., 2018).

Zerumbone has three double bonds, one isolated and two conjugated to the carbonyl group. Previous works had demonstrated the importance of the $\alpha, \beta$-unsaturated carbonyl group in the biological effects of zerumbone (Albaayit, 2021b; Murakami et al., 2002). This group was responsible for its versatile biological activities, including induction of apoptosis (Kim et al., 1996), cytoprotective activity (Rodriguez et al., 1997), glutathione S-transferase activity (Tjalkens et al., 1998), regulation of the insulin-like growth factor-I, and Waf-1 gene expressions (Bui and Straus, 1998).

Until now, no details for antibacterial mechanism of actions of zerumbone have been reported. The present study determined the mechanism of anti-MRSA effects of zerumbone using the AFM, SEM and flow cytometry techniques. The ultra-structural analyses of MRSA showed that treatment with zerumbone caused the scattering of the cytoplasmic content of dead cells as the result of cell membrane disruptions and loss of cellular integrity. The bacteria-killing effect of zerumbone was further confirmed by fluorescent $\operatorname{DiBAC}_{4}(3)$ and PI dye uptake. Zerumbone increased intake of $\operatorname{DiBAC}_{4}(3)$ and $\mathrm{PI}$ dye by MRSA by causing bacterial membrane depolarization and increasing membrane permeability (McAuley et al., 2018). The $\alpha, \beta$-unsaturated carbonyl group of zerumbone is suggested to be responsible for its cell membrane rupturing effect. Oritavancin, a glycopeptide antibiotic, is known to cause $S$. aureus membrane depolarization and increase cell mem- 
brane permeability, whereas cell wall synthesis inhibitor, vancomycin, has little effect on cell membrane potential and membrane permeability (Belley et al., 2010). To confirm this, more detailed studies related to membrane disruption mechanism need to be carried out, such as leakage of calcein-AM assay, lowering of zeta potential of bacteria, leakage of intracellular potassium ions, etc.

Compounds with antioxidant properties are ideal candidates for antibacterial drugs (Albaayit et al., 2014, 2015, 2016, 2019). In our study, ROS generation by MRSA was determined using the DCFDA fluorescence dye intake. Healthy nontreated bacterial cells produce ROS as a natural side effect of aerobic respiration (Albaayit et al., 2021d; Imlay and Fridovich, 1991). ROS can damage RNA/DNA and oxidize lipids in cells. Bacteria protect themselves against the effects of ROS by producing catalase and superoxide dismutase to detoxify the oxidant. Our study showed that zerumbone reduced ROS production by the MRSA. Apparently, the anti-MRSA activities of zerumbone are via mechanisms other than that causing bacterial self-destruction through the increased production of ROS. The scavenging effect of zerumbone toward the free radical was also proved by (Albaayit and Maharjan, 2018).

The toxicity profile of zerumbone has been measured in sprague dawley rats, BALB/c mice, and imprinting control regions (ICR) mice, in which the lethal dose was found to be higher than $500 \mathrm{mg} / \mathrm{kg}$ with non-toxic effects on vital organs (Ibrahim et al., 2010, Jin et al., 2013). Zerumbone is also non-hemolytic to human red blood cells (Albaayit et al., 2021a).

\section{Conclusions}

This study showed that zerumbone exerts its anti-MRSA effect by causing membrane depolarization and increasing membrane permeability, which resulted in the disruption of bacterial cell membrane.

\section{Acknowledgements}

The authors are very grateful to NAM-ICCBS (International Center for Chemical and Biological Sciences, University of Karachi, Karachi, Pakistan), and Prof. Dr. M. Iqbal Choudhary (Director, ICCBS) for Fellowship Award to Shaymaa Fadhel Abbas Albaayit.

\section{Ethical aspects and conflict of interests}

The authors have no conflict of interests to declare.

\section{References}

Abdul AB, Abdelwahab SI, Al-Zubairi AS, Elhassan MM, Murali SM (2008). Anticancer and antimicrobial activities of zerumbone from the rhizomes of Zingiber zerumbut. Int J Pharmacol 4(4): 301-304. DOI: 10.3923/ijp.2008.301.304.

Al-Ani LKT, Yonus MI, Mahdii BA, Omer MA, Taher JK, Albaayit SFA, Al-Khoja SB (2018). First record of use Fusarium proliferatum fungi in direct treatment to control the adult of wheat flour Tribolium confusum, as well as, use the entomopathogenic fungi Beauveria. Ecol Environ Conserv 24 (3): 29-34.

Albaayit SFA (2020). In vitro evaluation of anticancer activity of Moringa peregrina seeds on breast cancer cells. Eurasia Proc Sci Technol Eng Math 11: 163-166.

Albaayit SFA (2021a). Evaluation of anti-methicillin resistant Staphylococcus aureus property of Clausena excavata leaves by using atomic force microscopy and flowcytometry techniques. Pak J Agri Sci 58(1): 315-320. DOI: 10.21162/PAKJAS/21.921.

Albaayit SFA (2021b). Enzyme inhibitory properties of zerumbone. Pak J Agri Sci 58(3): 1207-1209. DOI: 10.21162/ PAKJAS/21.9759.

Albaayit SFA, Maharjan R (2018). Immunomodulation of Zerumbone via Decreasing the Production of Reactive Oxygen Species from Immune Cells. Pak J Biol Sci 21(9): 475-479. DOI: $10.3923 /$ pjbs.2018.475.479.

Albaayit SFA, Ozaslan M (2019). Cytotoxic and Urease Inhibition Potential of Moringa peregrina Seed Ethanolic Extract. Int J Pharmacol 15(1): 151-155. DOI: 10.3923/ijp.2019.151.155.

Albaayit SFA, Abba Y, Abdullah R, Abdullah N (2014). Evaluation of antioxidant activity and acute toxicity of Clausena excavata leaves extract. Evid Based Complement Alternat Med 2014: 975450. DOI: $10.1155 / 2014 / 97545$.

Albaayit SFA, Abba Y, Abdullah R, Abdullah N (2015). Effect of Clausena excavata Burm. F. (Rutaceae) leaf extract on wound healing and antioxidant activity in rats. Drug Des Devel Ther 9: 3507-3518. DOI: 10.2147/DDDT.S84770.

Albaayit SFA, Abba Y, Abdullah R, Abdullah N (2016). Prophylactic effects of Clausena excavata Burum. f. leaf extract in ethanolinduced gastric ulcers. Drug Des Devel Ther 10: 1973-1986. DOI: 10.2147/DDDT.S103993.

Albaayit SFA, Abdullah R, Abdullah N (2020a). Zerumbone-loaded nanostructured lipid carrier gel facilitates wound healing in rats. Rev Bras Farmacogn 30(2): 272-278. DOI: 10.1007/s43450-02000023-7.

Albaayit SFA, Al-Khafaji ASK, Alnaimy HS (2019). In vitro macrophage nitric oxide and interleukin-1 beta suppression by Moringa peregrina seed. Turk J Pharm Sci 16(3): 362-365. DOI: 10.4274/tips.galenos.2018.52244.

Albaayit SFA, Khan MA, Abdullah R (2021c). Zerumbone induces growth inhibition of Burkitt's lymphoma cell line via apoptosis. Nat Volatiles Essent Oils 8(3): 56-63. DOI: 10.37929/ nveo.927770.

Albaayit SFA, Khan MA, Abdullah R, Noor MHM (2021d). Ethyl acetate extract of Clausena excavata induces growth inhibition of non-small-lung cancer, NCI-H460, cell line via apoptosis. J Appl Biomed 19(1): 40-47. DOI: 10.32725/jab.2021.007.

Albaayit SFA, Maharjan R, Abdullah R, Noor MHM (2021b). AntiEnterococcus faecalis, Cytotoxicity, Phytotoxicity, and Anticancer Studies on Clausena excavata Burum. f. (Rutaceae) Leaves. Biomed Res Int 2021: 3123476. DOI: 10.1155/2021/3123476.

Albaayit SFA, Maharjan R, Khan M (2021a). Evaluation of hemolysis activity of Zerumbone on RBCs and brine shrimp toxicity. Baghdad Sci J 18(1): 65-69. DOI:10.21123/bsj.2021.18.1.0065.

Albaayit SFA, Rasedee A, Abdullah N, Abba Y (2020b). Methanolic extract of Clausena excavata promotes wound healing via antiinflammatory and anti-apoptotic activities. Asian Pac J Trop Biomed 10(5): 232-238. DOI: 10.4103/2221-1691.281467.

Al-Bahrani RM, Radif HM, Albaayit SFA (2020). Evaluation of potent silver nanoparticles production from Agaricus bisporus against Helicobacter pylori. Pak J Agri Sci 57(4): 1197-1201. DOI: 10.21162/PAKJAS/20.9893.

Al-Naddawi THS, Albaayit SFA, Khalaf ZZ (2019). The Synergism and Antagonism behavior of Aqueous Extraction for Black Tea, Green Tea and Coffee against the Effectiveness of Certain Antibiotics. Eurasia Proc Sci Technol Eng Math 6: 39-42.

Ashraf SM, Sebastian J, Rathinasamy K (2019). Zerumbone, a cyclic sesquiterpene, exerts antimitotic activity in HeLa cells through tubulin binding and exhibits synergistic activity with vinblastine and paclitaxel. Cell Prolif 52(2): e12558. DOI: 10.1111/cpr.12558.

Belley A, McKay GA, Arhin FF, Sarmiento I, Beaulieu S, Fadhil I, et al. (2010). Oritavancin disrupts membrane integrity of Staphylococcus aureus and vancomycin-resistant enterococci to effect rapid bacterial killing. Antimicrob Agents Chemother 54(12): 53695371. DOI: 10.1128/AAC.00760-10.

Benbelaïd F, Khadir A, Abdoune MA, Bendahou M, Muselli A, Costa J (2014). Antimicrobial activity of some essential oils against oral multidrug-resistant Enterococcus faecalis in both planktonic and biofilm state. Asian Pac J Trop Biomed 4(6): 463-472. DOI: 10.12980/APJTB.4.2014C1203. 
Bui T, Straus DS (1998). Effects of cyclopentenone prostaglandins and related compounds on insulin-like growth factor-I and Waf1 gene expression. Biochim Biophys Acta 1397(1): 31-42. DOI: 10.1016/S0167-4781(97)00214-5.

Clementi EA, Marks LR, Roche-Håkansson H, Håkansson AP (2014). Monitoring changes in membrane polarity, membrane integrity, and intracellular ion concentrations in Streptococcus pneumoniae using fluorescent dyes. J Vis Exp 84: e51008. DOI: $10.3791 / 51008$.

da Silva TM, Pinheiro CD, Orlandi PP, Pinheiro CC, Pontes GS (2018). Zerumbone from Zingiber zerumbet (L.) smith: a potential prophylactic and therapeutic agent against the cariogenic bacterium Streptococcus mutans. BMC Complement Altern Med 18(1): 301. DOI: 10.1186/s12906-018-2360-0.

Dhama K, Tiwari R, Chakraborty S, Saminathan M, Kumar A, Karthik K, et al. (2014). Evidence based antibacterial potentials of medicinal plants and herbs countering bacterial pathogens especially in the era of emerging drug resistance: An integrated update. Int J Pharmacol 10(1): 1-43. DOI: 10.3923/ijp.2014.1.43.

Fang Z, Xu L, Lin Y, Cai X, Wang S (2019). The preservative potential of Octopus scraps peptides-Zinc chelate against Staphylococcus aureus: Its fabrication, antibacterial activity and action mode. Food control 98: 24-33. DOI: 10.1016/j.foodcont.2018.11.015.

Farooq S, Wahab AT, Fozing CD, Rahman AU, Choudhary MI (2014). Artonin I inhibits multidrug resistance in Staphylococcus aureus and potentiates the action of inactive antibiotics in vitro. J Appl Microbiol 117(4): 996-1011. DOI: 10.1111/jam.12595.

Fischer ER, Hansen BT, Nair V, Hoyt FH, Dorward DW (2012). Scanning Electron Microscopy. Curr Protoc Microbiol 25: 2B.2.12B.2.47. DOI: 10.1002/9780471729259.mc02b02s25.

Girisa S, Shabnam B, Monisha J, Fan L, Halim CE, Arfuso F, et al. (2019). Potential of zerumbone as an anti-cancer agent. Molecules 24(4): 734. DOI: 10.3390/molecules24040734.

Hwang S, Jo M, Hong JE, Park CO, Lee CG, Yun M, Rhee K-J (2019). Zerumbone Suppresses Enterotoxigenic Bacteroides fragilis Infection-Induced Colonic Inflammation through Inhibition of NF-кB. Int J Mol Sci 20(18): 4560. DOI: 10.3390/ijms20184560.

Ibrahim MY, Abdul AB, Ibrahim TAT, Abdelwahab SI, Elhassan MM, Syam MM (2010). Evaluation of acute toxicity and the effect of single injected doses of zerumbone on the kidney and liver functions in Sprague Dawley rats. Afr J Biotechnol 9(28): 4442-4450.

Ibraheem HT, Al-Mathkhury HJF (2018). pvl-carried methicillin resistant Staphylococcus aureus isolated from hospitalized patients in Baghdad, Iraq. Iraqi J Sci 59(4B): 1967-1972. DOI: 10.24996/ ijs.2018.59.4B.1.

Imlay JA, Fridovich I (1991). Superoxide production by respiring membranes of Escherichia coli. Free Radic Res Commun 12-13 Pt 1: 59-66. DOI: 10.3109/10715769109145768.

Jin YB, Seo WD, Lee YJ, Lee YS, Lee HJ (2013). Toxicological evaluation of zerumbone on antitumor effects in mice. Afr J Pharm Pharmacol 7(8): 466-473. DOI: 10.5897/ AJPP2012.0001.

Kalantari K, Moniri M, Boroumand Moghaddam A, Abdul Rahim R, Bin Ariff A, Izadiyan Z, Mohamad R (2017). A review of the biomedical applications of zerumbone and the techniques for its extraction from ginger rhizomes. Molecules 22(10): 1645. DOI: $10.3390 /$ molecules22101645.

Kim HS, Lee JH, Kim IK (1996). Intracellular glutathione level modulates the induction of apoptosis by $\Delta 12$-prostaglandin J2. Prostaglandins 51(6): 413-425. DOI: 10.1016/00906980(96)00047-0.

Kitayama T, Iwabuchi R, Minagawa S, Sawada S, Okumura R, Hoshino K, et al. (2007). Synthesis of a novel inhibitor against MRSA and VRE: preparation from zerumbone ring opening material showing histidine-kinase inhibition. Bioorg Med Chem Lett 17(4): 1098-1101. DOI: 10.1016/j.bmcl.2006.11.015.

Lancaster MV, Fields RD (1996). Antibiotic and cytotoxic drug susceptibility assays using resazurin and poising agents. U.S. Patent No. 5,501,959A. Washington DC: U.S. Patent and Trademark Office.

McAuley S, Huynh A, Czarny TL, Brown ED, Nodwell JR (2018) Membrane activity profiling of small molecule $B$. subtilis growth inhibitors utilizing novel duel-dye fluorescence assay. MedChemComm 9(3): 554-561. DOI: 10.1039/c8md00009c.

Mudzengi CP, Murwira A, Tivapasi M, Murungweni C, Burumu JV, Halimani T (2017). Antibacterial activity of aqueous and methanol extracts of selected species used in livestock health management. Pharm Biol 55(1): 1054-1060. DOI: 10.1080/13880209.2017.1287744.

Murakami A, Takahashi D, Kinoshita T, Koshimizu K, Kim HW, Yoshihiro A, et al. (2002). Zerumbone, a Southeast Asian ginger sesquiterpene, markedly suppresses free radical generation, proinflammatory protein production, and cancer cell proliferation accompanied by apoptosis: the $\alpha, \beta$-unsaturated carbonyl group is a prerequisite. Carcinogenesis 23(5): 795-802. DOI: 10.1093/ carcin/23.5.795.

Rodríguez AM, Enriz RD, Santagata LN, Jáuregui EA, Pestchanker MJ, Giordano OS (1997). Structure-cytoprotective activity relationship of simple molecules containing an $\alpha, \beta-$ unsaturated carbonyl system. J Med Chem 40(12): 1827-1834. DOI: 10.1021/jm960280m.

Santosh Kumar SC, Srinivas P, Negi PS, Bettadaiah BK (2013). Antibacterial and antimutagenic activities of novel zerumbone analogues. Food Chem 141(2): 1097-1103. DOI: 10.1016/j. foodchem.2013.04.021.

Siddique H, Pendry B, Rahman MM (2019). Terpenes from Zingiber montanum and Their Screening against Multi-Drug Resistant and Methicillin Resistant Staphylococcus aureus. Molecules 24(3): 385 DOI: $10.3390 /$ molecules24030385.

Sithara T, Dhanya BP, Arun KB, Sini S, Dan M, Kokkuvayil Vasu R, Nisha P (2018). Zerumbone, a cyclic sesquiterpene from Zingiber zerumbet induces apoptosis, cell cycle arrest, and antimigratory effects in SW480 colorectal cancer cells. J Agric Food Chem 66(3): 602-612. DOI: 10.1021/acs.jafc.7b04472.

Tian M, Wu X, Hong Y, Wang H, Deng G, Zhou Y (2020). Comparison of chemical composition and bioactivities of essential oils from fresh and dry rhizomes of Zingiber zerumbet (L.) Smith. Biomed Res Int 2020: 9641284. DOI: 10.1155/2020/9641284.

Tjalkens RB, Luckey SW, Kroll DJ, Petersen DR (1998). $\alpha, \beta$-Unsaturated Aldehydes Increase GlutathioneS-Transferase mRNA and Protein: Correlation with Activation of the Antioxidant Response Element. Arch Biochem Biophys 359(1): 42-50. DOI: 10.1006/abbi.1998.0895.

Vishwanatha HN, Niraguna Babu P, Gowrishankar BS, Shridhar SB (2012). Antimicrobial activity of zerumbone from Zingiber zurumbet against Staphylococcus epidermidis and Aspergillus spp. IJABPT 3(4): 40-43.

Wu Y, Bai J, Zhong K, Huang Y, Qi H, Jiang Y, Gao H. (2016). Antibacterial activity and membrane-disruptive mechanism of 3-p-trans-coumaroyl-2-hydroxyquinic acid, a novel phenolic compound from pine needles of Cedrus deodara, against Staphylococcus aureus. Molecules 21(8): 1084. DOI: 10.3390/ molecules21081084.

Zhang S, Liu Q, Liu Y, Qiao H, Liu Y (2012). Zerumbone, a Southeast Asian ginger sesquiterpene, induced apoptosis of pancreatic carcinoma cells through p53 signaling pathway. Evid Based Complement Alternat Med 2012: 936030. DOI: 10.1155/2012/936030. 